\title{
Cilinaya (The Ecocritic Analysis of Literature in The Folklore of Sasak People in Lombok)
}

\author{
Hilmiyatun ${ }^{1}$, Sarwiji Suwandi ${ }^{2}$, Herman J.Waluyo ${ }^{3}$, Nugraheni Eko Wardani ${ }^{4}$ \\ ${ }^{1234}$ Fakultas Keguruan dan Ilmu Pendidikan, Universitas Sebelas Maret, Surakarta, Indonesia \\ 1hilmiya@student.uns.ac.id, ${ }^{2}$ sarwijiswan@staff.uns.ac.id \\ ${ }^{3}$ hermanjwaluyo@yahoo.co.id, ${ }^{4}$ buheniwardani@gmail.com
}

\begin{abstract}
This article aims to explain the value of environmental wisdom contained in the folklore of Cilinaya. Cilinaya is one of the folklores of the Sasak people in Lombok which was translated into Indonesian and archived by the West Nusa Tenggara Museum in 2007. The value of environmental wisdom in this folklore is explained using ecocritic analysis of literature combined with semiotic theory. This research is a qualitative descriptive using content analysis method. The data source in this research is the folklore of Cilinaya. The results of this research revealed that there are some values of environmental wisdom in this folklore in the form of (1) respect for nature; (2) moral responsibility for nature; and (3) proportional utilization of nature. These aforementioned values belong to the tradition of Sasak people in Lombok being inherited from generation to generation.
\end{abstract}

Keywords: cilinaya, ecocritic of literature, folklore, Lombok

\section{INTRODUCTION}

The condition of nature that has deteriorated in recent years has come to the attention of many parties. Lombok is one of the islands in Indonesia that has it. This phenomenon is proven by 41 flood disaster, 6 landslide disaster, $32.75 \%$ water pollution, $3.65 \%$ land pollution, and $9.27 \%$ air pollution [1]. The aforementioned numbers prove that the destruction of nature cannot be separated from the hands of people who are no longer afraid of violating the existing customary norms. Overcoming this ecological crisis is not merely a technical matter, but needs to be traced to the spiritual intricacies of the people that have been obtained for generations in order to maintain the balance of nature around them.

At present the West Nusa Tenggara government prioritizes economic growth to improve the welfare of the people. Furthermore, after carrying out the halal tourism program in accordance with the regulations of the West Nusa Tenggara government in 2015 [2] [3], Lombok is now crowded with tourists. This condition leads to creative economic growth, employment opportunity, improvement of people's welfare and poverty reduction in the local area. In addition to the positive impacts felt directly by the Sasak people, this condition actually has a greater negative 
impact. This kind of activity is a form of exploitation of natural resources that is centered on personal interests and certain needs.

Responding to environmental problems that recently continue to grow motivates the researcher to study several aspects related to the environment. Basically, the environmental issue is often discussed by researchers. The research of Dudareva et al. and Xu and Nangon through poetry explored various ecological wisdom in it [4] [5]. It is by means of this research, the researcher wants to build a positive synergy between the people and nature in preserving local wisdom through folklore owned by the Sasak people in Lombok. Ecocritic analysis of literature is expected to help determine, explore, and even provide solutions to environmental problems [6]. Ecocritic is the study of the relationship between literature and physical environment [7]. Ecocritic wants to track ideas of the environment and its representation [8]. The presence of ecocritic gives attention to the interrelationship between literature and the environment, including cultural and physical reality, which are usually concerned in ecology. It is because literature is a reflection of the condition of the environment [9] .

Cilinaya folklore is one of the Sasak folklore in Lombok which has been documented by the West Nusa Tenggara Museum in 2007 [10]. Cilinaya folklore reveals various cultural portraits of the Sasak people that are well recorded in each plot. This folklore tells the story of the struggle of the Daha kingdom and Keling kingdom in obtaining offspring. Many things expressed in this story use symbols as a form of representation of the disclosure of the natural surroundings .

Research on folklore has previously been studied by Zolotova. She revealed the structure of stories formed through the recorded history of people's lives using Pladimir Vropp's narratology analysis [11]. In line with this, Research on folklore of Sasak people in Lombok is limited to the structure of narrative elements [12], the structure of texts, the co-text and context of oral traditions [13], the form and meaning of narrative expressions [14]. Thus, this research analyzes the value of environmental wisdom in Cilinaya folklore through ecocritic analysis of literature.

\section{METHOD}

This research uses a qualitative descriptive approach with literature review and content analysis. The research data were obtained through Cilinaya folklore. The data source is in the form of the Cilinaya folklore script which was published in 2007 by the Culture and Tourism Office of West Nusa Tenggara Province. This folklore consists of 154 pages and is well documented by the state museum of West Nusa Tenggara Province. The folklore was analyzed using ecocritic analysis of literature [8] [9] to explain the value of environmental wisdom in Cilinaya folklore. Furthermore, semiotic analysis was used to explain the meaning of signs or symbols which have the values of environmental wisdom contained in the text. The analysis continued with drawing conclusions based on the research theme.

\section{RESULTS AND DISCUSSION}

In Cilinaya folklore, some environmental wisdom values appear through the story texts in the form of words, phrases, clauses, sentences or through symbols or signs. The analysis of the values of environmental wisdom in Cilinaya folklore refers to Keraf's premise, namely: (1) respect for nature; (2) moral responsibility for nature; (3) cosmic solidarity; (4) caring for nature; 
(5) the principle of "no harm"; (6) living simply and in harmony with nature; (7) the principle of justice; and (8) the principle of democracy [15]. Cilinaya folklore has several values of environmental wisdom in it.

3.1. Respect for Nature. This value is contained in the following quote:

(8) Raja Daha segera berangkat ke tempat saudaranya. Laki perempuan pada ramai mengiringi sang raja. Para bangsawan dan mantri juga ikut mengiringi, kemudian mereka telah sampai di Kayangan, semuanya. Semuanya menghadap dan melaporkan beserta sanak keluarganya. (9) Tak lama semuanya mandi dan raja Daha bersama saudaranya laki perempuan semua ramai. Raja Daha mengeluarkan (kaulnya). Bila kelak saya dikaruniai anak perempuan, maka saya akan membayar (kaulku). Akan memotong dua ekor kerbau. (10) Kerbaunya berkulit emas dan perak murni, ekornya dari sutra warna kuning. Itulah bunyi janji (kaulnya). Janji (kaul) sang raja kaulnya datu Daha. Dan raja Keling pun berjanji. Bila nanti saya (11) Bila doaku diterima, oleh sang Batara, mempunyai anak lakilaki saya akan datang kembali. Saya mandikan diriku dengan membawa pinang sebelah, sirih kering selembar, tembakau sepenyusur, itulah janji (kaul) nya raja Keling (Cilinaya, hal. 11-13).

(8) Raja Daha immediately departed to his brother's place. Men and women in the crowd accompanied the king. The nobles and paramedics also accompanied, then they arrived at Kayangan, all of them. Everyone faced and reported with their relatives. (9) In a short time, everyone took a shower and King Daha and his family were all busy. King Daha took out his vow. When I am blessed with a daughter, I will pay for it (my vow). Will butcher two buffalos. (10) The buffalos are skinned with pure gold and silver, the tail is of yellow silk. That was his vow (his kaul). The vow (kaul) was King Daha's vow. And the king Keling also vowed. If later I (11) If my prayer is received, by the Batara, having a son, I will come back. I bathe myself by bringing an adjoining betel nut, a piece of dried betel, snuff tobacco, that is the vow (kaul) of the king Keling (Cilinaya, pp. 11-13).

In the quote above it is explained that "kayangan" is a place visited by the king with his nobles and paramedics. Kayangan is also described as a bathing place for the king and his family. In this place also, the king Daha and the king Keling finally decided to state their vows (their $\mathrm{kaul}$ ). That is, this place is a place that is not usually visited by haphazard people. So "kayangan" is a special place for king Daha and king Keling. "Kayangan" is a sign. A sign is something that is interpreted [16]. Because it is considered as a place that can be interpreted, "kayangan" is a privileged place. As a special place, it is logically impossible for a king to give his vows anywhere. He must have known when and where he had to make the vow.

"Telah sampai di kayangan" explains that visiting "kayangan" is a form of respect for nature. By visiting, is a form of attitude to respect the existence of nature "kayangan". Furthermore, the expression of these vows is certainly believed that "kayangan" is a special or extraordinary place. Therefore, the Sasak people in Lombok must maintain and preserve it. Visiting even to vow in "kayangan" is part of the actions taken by the people to protect the ecosystem there.

In addition, the cosmic act as performed by king Daha and king Keling is "visiting and praying" at that place. The prayers offered by king Daha and king Keling are in the form of vows 
if given offspring. King Daha vowed that if he was given a daughter offspring, he would come to "kayangan" to pay his vow by butchering two buffaloes with pure gold and silver skin, tails made of yellow silk. Whereas king Keling vowed that if he was given a son offspring, he would pay his vow by coming to "kayangan" while bathing himself by bringing an adjoining betel nut, a piece of dried betel and snuff tobacco. The aforementioned acts prove that humans must have morals in respecting nature. Therefore, humans have a moral responsibility to respect nature [15].

The desire to pay for the vows and offerings that will be done by king Daha and king Keling if their prayers are granted is an act to preserve nature. Because through "kayangan" the attitudes of respect for nature were proven by coming back to "kayangan", for the vows that had been made there.

3.2. Responsibility for Nature, contained in the following quote:

(25) Pergi ke Kayangan membayar kaulnya, raja Daha mengingkari janjinya. Lupa pada janjinya terdahulu. Pergi tak tau arah. Raja Keling menyiapkan bebek dan ayam dan tiga ekor kerbau, juga tanduk emas, dan kakinya terbuat dari selaka dan bertatah. Juga seekor sutra warna merah. (26) Kemudian raja pun segera berangkat. Raja Daha pergi bersamasama. Laki perempuan semuanya ramai bersama dengan sang raja. Para kahula dan priyayi ramai laki dan perempuan berjalan mengirngi sang raja. Tak lama dalam perjalanan kemudian telah sampai. (27) Tak lama mereka pun mandi. Raja Daha mengajak saudaranya laki perempuan. Setelah mereka mandi mereka pun berangkat pulang. Selesai berpakaian, ada yang menggunakan kain warna dadu juga akan memakai perhiasan emas raja Daha. Kemudian raja Keling ramai makan bersama-sama. (28) Setelah mereka dalam perjalanan, raja Daha tidak membawa apa-apa semuanya terasa tidak enak. Jadi semuanya raja Daha dan raja Keling akan berangkat kemudian mereka tiba. Karena tadir Tuhan anaknya sang raja diterbangkan oleh angin. Anaknya sang raja Daha (Cilinaya, hal. 25-23).

(25) Going to Kayangan to pay his vows, the king Daha reneged on his vows. Forgetting the previous vows. Going without knowing the direction. The king Keling prepared ducks and chickens and three buffaloes, as well as golden horns, and their legs were made of "selaka" and inlaid. Also red silk. (26) Then the king departed immediately. King Daha left together. The men and women were all busy with the king. The "kahula" and "priyayi" were crowded with men and women walking alongside the king. Shortly after the journey arrived. (27) Soon they took a bath. King Daha invited his sister and brother. After they bathed, they left for home. Finished dressed, one using dice cloth will also wear king Daha's gold jewelry. Then the king Keling ate together. (28) After they were on their way, the king Daha did not bring anything with everything. So, the king Daha and the king Keling would depart then they arrived. Because of The God's grace, the king's son was blown away by the wind. He was the son of king Daha (Cilinaya, pp. 25-23).

In this excerpt, it is explained that nature (kayangan) is an embodiment of God's greatness. So that any vows to God (through intermediately kayangan) are kept. King Keling returned to "kayangan" to pay his vows to God. In fact, he paid the vows more than what had been vowed in that place. Unlike the king Daha. He was negligent at the vows he had made at the place of God's embodiment. Being granted his prayer through the "kayangan" made him more focused on his 
daughter. Though the child was born as a form of prayer grant to the vows he had made in that place. Here, "paying for vows" is an expression of responsibility to nature "kayangan".

This responsibility is certainly an obligation that must be fulfilled. Because, previously the king Keling and the king Daha had vowed in that place. If the responsibility of nature (through kayangan) is not fulfilled by them, there will be misfortune that can harm themselves. As experienced by king Daha. He forgot his responsibility to pay for the vow to the "kayangan". Finally, bad things happened to him. His only daughter was flown by the wind because he did not do his responsibility to nature. "Blown by the wind" is a result of its devotion to nature. Thus, he got the consequence of not fulfilling his responsibility to nature. Because, every part and object in the universe was created by God with its respective goal, regardless of whether the purpose is for human interest or not, humans as part of nature must be responsible for protecting it [15].

3.3. Proportional Use of Nature, contained in the following quote:

(161) Sang puteri juga mengatakan. Sayang kamu anak telah lama sengsara. Seandainya seperti buah jambu kuning. Kupaksakan akan memakannya. (162) Juru potong semakin keras perintahnya. Apakah kamu sudah memandikannya. Sang Puteri mengatakan manis. Nanti dulu akan kuberikan boreh. (163) Lalu dia memboreh sang puteri, sambil meneteskan air mata. Memang nasibmu anakku gusti. Sangat sayang kamu segsara. (164) Seandainya kamu jadi kembang anakku, saya menjadi kumbang yang terbang mencari sari bunga yang manis. Saya kumbang menghisap kembang (Cilinaya hal. 79-80).

(161) The princess also said. Unfortunately you child has been miserable for a long time. If only like yellow guava fruit. I will eat it. (162) The clerk orders the harder. Did you bathe him The Princess said sweetly. I'll give "boreh" to you first. (163) Then he incised the princess, tears in his eyes. Indeed, your fate my child is leprosy. Very, unfortunately, you are miserable. (164) If you had become my child's flower, I would have become a beetle that flew looking for sweet flower essence. I am a beetle sucking flowers (Cilinaya, pp. 79-80).

Here, the value of environmental wisdom in the form of proportional use of nature is indicated by the word "boreh". "Boreh" is a sign that is interpreted as an herb or drink made from spices. "Boreh" is also interpreted as a processed spice used as medicine by the Sasak people in Lombok. "Boreh" is the result of utilizing nature processed from spices. The utilization of this spice shows that Indonesia is rich in agricultural products so it needs to be utilized in accordance with the needs of the surrounding people, including the Sasak people. This Cilinaya folklore is a piece of historical evidence that Sasak people in Lombok still use "boreh" as a mask, herb or traditional treatment until now.

In addition to the Sasak people, other people also use traditional medicine for generations, namely the Balinese [15] [16] [17], the Tengger people [18], the Kalimantan people [19]. The use of traditional medicine for people in various regions is aiming at preserving the local wisdom they have [20].

\section{CONCLUSION}

The values of environmental wisdom contained in the Cilinaya folklore are the attitudes of the Sasak people in Lombok which are inherited from generation to generation. The values of 
environmental wisdom in Cilinaya folklore includes: (1) Respect for nature; this attitude is demonstrated by the activity of visiting or praying to an area called "kayangan". "Kayangan" is the name of a place that represents nature. So kayangan (nature) must be respected by visiting or praying there; (2) Responsibility for nature; this attitude is shown by paying for prayers (vows) to nature (kayangan). Attitude to pay for vows is proof of responsibility towards nature because it has vowed to nature. That is, whatever form of action taken by someone or the people to nature, the person or the people must be responsible for the action; and (3) Proportional utilization of nature; this attitude is shown by utilizing nature to be "boreh". "Boreh" is the result of the utilization of nature made from processed spices and other plants that are used to produce herbs, drinks, and traditional medicine.

\section{REFERENCES}

[1] K. L. H. dan K. R. Indonesia, "Kerusakan Lingkungan Nusa Tenggara Barat," 2018.

[2] P. D. N. T. Barat, Peraturan Gebernur Nusa Tenggara Barat Nomor 51 Tahun 2015 tentang Wisata Halal. 2015.

[3] P.D.N. T Barat, Peraturan Daerah Provinsi Nusa Tenggara Barat Nomor 2 Tahun 2016 tentang Pariwisata Halal.

[4] Y. V. A. \& E. N. S. M. A. Dudareva, I.S Milovanova, "Mortal Subtext in O.E. Mandelstam's Poem 'Oh, How We Love to Be a Hypocrite': Folklore Reality," J. Soc. Stud. Educ. Res., vol. 8, no. 3, pp. 282-290, 2017.

[5] J. Xu \& M. Nangong. H.W, "Longfellow: A Poetical-Dwelling Poet of Ecological Wisdom from the Perspective of Eco-criticism,” J. English Lang. Teach., vol. 5, no. 5, pp. 85-100, 2012.

[6] G. Gerrard, Ecocriticism. New York: Routhledge, 2004.

[7] C. G. \& H. Fromm, Ed., The Ecocriticm Reader: Landmarks in Literary Ecology. London, 1996.

[8] R. K. \& N.Sammells, Ed., Writing the Environment. Londong: Zed Book, 1998.

[9] S. Endraswara, Ed., Sastra Ekologis: Teori dan Praktik Pengkajian. Yogyakarta: CAPS (Center for Academic Publishing Service, 2016.

[10] D. kebudayaan dan P. P. N. T. Barat, Ilinaya. Lombok: Dinas kebudayaan dan Pariwisata Provinsi Nusa Tenggara Barat, 2007.

[11] A. O. T. F. T.A. Zolotova, N.I. Efimova, E.A. Plotnikova, "Tale Traditions in Amateur and Professional Young Writers' Creativity,” J. Lang. Stud. (Gema Online), vol. 17, no. 4, pp. 101-112, 2017.

[12] Khaeriati, "The folktales of Lombok: Fairy Tales of Cupak Gerantang, Sandubaya and Lala Seruni, And Cilinayaa Narative Structural review of Vladimir Propp," J. Educatio., vol. 4, no. 1, pp. 13-31, 2009.

[13] N. N. Alaini, "Tradisi Lisan Cepung: Sastra Perlawanan Komunitas sasak Terhadap kekuasaan bali di pulau Lombok," J. Metasastra, vol. 8, no. 1, pp. 47-60, 2015.

[14] R. J. Alfanani, "Bentuk dan Makna ekspresi Naratif Cerita Rakyat Sasak Doyan Nedo: Kajian Ekortitik Sastra," J. Mabasindo, vol. 1, no. 1, pp. 65-74, 2017.

[15] S. A. Keraf, Etika Lingkungan Hidup. Jakarta: Kompas, 2010.

[16] H. S. P. Ahimsa, Strukturalisme Levi-Strauus. Yogyakarta: Kepel Press, 2012.

[17] Mu'jizah, "Naskah Usada sebagai Kearifan Lokal Masyarakat Bali," DIALEKTIKA, vol. 3, no. 2, pp. 191-200, 2016.

[18] I. Y. Ningsih, "Studi Etnofarmasi Penggunaan Tumbuhan Obat oleh Suku Tengger di Kabupaten Lumajang dan Malang, Jawa Timur," PHARMACY, vol. 13, no. 1, pp. 10-20, 2016.

[19] Y. Robi. at all,"Etnobotani Rempah Tradisonal di Desa Empoto Kabupaten Sanggau Kalimantan Barat," J. Hutan Lestari, vol. 7, no. 1, pp. 130-142, 2019. 
[20] .W. Setyawan and K. Saddhono, "Eret traditional ceremony as representation of spirit of mutual cooperation among coastal communities". Adv. Sci. Let. vol. 23 no.10, pp 9991-9992, 2017 